\title{
The Role of Dutch Colonialism in the Political Life of Mataram Dynasty: A Case Study of the Manuscript of Babad Tanah Jawi
}

\author{
Kundharu Saddhono $^{1} \&$ Siti Supeni ${ }^{2}$ \\ ${ }^{1}$ Sebelas Maret University, Indonesia \\ ${ }^{2}$ Slamet Riyadi University, Indonesia \\ Correspondence: Kundharu Saddhono, Sebelas Maret University, Jl. Ir. Sutami 36A Surakarta, Indonesia. E-mail: \\ kundharu.uns@gmail.com
}

Received: February 20, 2014 Accepted: April 4, 2014 Online Published: July 13, 2014

doi:10.5539/ass.v10n15p1

URL: http://dx.doi.org/10.5539/ass.v10n15p1

\begin{abstract}
This paper aims at describing the role of Dutch colonialism in the political life of Mataram Dynasty based on Javanese concept. This literature study is a qualitative descriptive study which reveals the role of Dutch colonialists within the text of History of the Land of Java (Babad Tanah Jawi). Babad Tanah Jawi narrates the ancestry of Javanese Kings initiated in the era of Prophet Adam who brings forth further prophets and gods. It also narrates the enthronement of gods in Jawa Dwipa (the land of Java) which lasted until Mataram Dynasty in Kartasura. Babad Tanah Jawi is considered having the function to legitimate the authority of Mataram Kingdom. This manuscript considers Mataram Kingdom as the official hegemony of the rulers in Java which is Majapahit. In the glorious period of Kanjeng Sultan Agung Senapati Ingalaga Ngabdurrachman in 1571, Dutch people were reported to have occupied Jayakarta. This research limits the study into the investigation of two prominent motives which are prophecy motive and mutualism political motive between Mataram Kingdom and The Dutch colonialists. The information narrated in Babad Tanah Jawi should not be considered historical. Babad Tanah Jawi should be valued as a Javanese mindset and approach in praising their Kings and motherland. For Javanese people, the interpretation of pralambang, symbols, is far more valuable than only factual reading. In conclusion, based on 'Javaneseness' intuitive approach, it was not Dutch colonialists who controlled the political system of Mataram Kingdom. It was Javanese politicians who were considered as the controller and actor of Javanese political scenarios.
\end{abstract}

Keywords: Mataram Dynasty, prophecy motive, political motive, Babad Tanah Jawi, Dutch colonialism

\section{Introduction}

History of the land of Java or originally known as Babad Tanah Jawi is a Javanese literature that can be formally classified as a great work. The manuscript of History of the Land of Java is available in several printed and published versions. Different versions of a historical literature are frequently analyzed in literature research perspective (Kumar, 1984; Johns, 1964; Berg, 1964). This is shown from various researches conducted (Ras, 1986; 1987; Wieringa, 1999; Day, 1978; Ricklefs, 1979). The manuscript was written in the era of Susuhunan Pakubuwana IV during 1788-1820, rewritten by Dutch colonialists, and published by Balai Pustaka. Another version of History of the Land of Java is Meinsma's manuscript which was written in the form of prose. This research is not a historical research trying to find factual truths; instead this is a literature research focusing on the prose manuscript of History of the land of Java transliterated and translated by Sudibjo Z. H, which from this point forward will be referred to as BTJ-S; published in 1980 by The Publishing Project of Indonesian and Regional Literature Books, The Ministry of Education and Culture, Jakarta. This manuscript is considered a new version that can enrich Indonesian national and regional literature.

BTJ-S recounts the ancestry of the kings of Java; beginning from Prophet Adam, the father of humankind and future prophets, gods and goddesses. There are several major stories in BTJ-S, some of them are: the history of King Watugunung that was the antecedent of the calculation of wuku (Javanese calendar system); the story of Siyung Wanara (banyak Wide), the king of Padjadjaran; the story of Majapahit Kingdom, Demak Sultanate, Pajang Sultanate, and Mataram Kingdom; and the story of Mataram Dynasty in Kartasura Palace during the reign of Pakubuwana II. 
This research focuses on a text reciting the role of Dutch colonialism in the political life of Mataram Dynasty. The text analyzed is an excerpt from BTJ-S page 176-470. The first reference of "Dutch people" in BTJ-S is found on page 176, in the story happening during the reign of King Agung Hanyakrakusuma in 1571.

The name "Mataram" in the context of this research refers to the dynasty which was the descendant of Panembahan Senapati (Inggalaga) which ruled the Mataram Kingdom (now located within the Special District of Yogyakarta). On February 21, 1755, Mataram Dynasty was disunited into two: Kasunanan Surakarta Hadiningrat and Kasultanan Ngayogjakarta Hadiningrat (Poensen in Ricklefs, 2002: 107). The disunity is also related to the fall or collapse of Majapahit Kingdom (Ricklefs, 1972).

BTJ-S is a historical type of literature (babad). Babad is a type of manuscript that gives meaning to the items vital for a certain community (Teeuw, 1984: 241). Culture and literature is an open system closely related to each other because literature is an integrated part of culture. BTJ-S manuscript and the other versions of History of the Land of Java have a profounder meaning than merely historical. According to Teeuw, historical literatures like BTJ-S are written to give greater mystical value to a fictional narrative. The genealogy within the script is not related to general history, instead it exists only in the structure of the literature itself (1988: 342-344).

The objective of the research is to analyze one major problem of how to describe the role of Dutch colonialism in the political life of Mataram Dynasty based on BTJ-S. This problem has been previously mentioned in a research conducted by Fitzpatrick (2008). The problem is observed from the point of view of Javanese insight implied in the text of BTJ-S in order to identify the characteristics of the text. In other words, this research views the text outside the text; given the fact that the issue of society representation is a symbolic representation of a universal matter or an incorporation of particulars (Hartarta, 2011: 51).

\section{Research Methodology}

The research is a descriptive qualitative research. The data used in the research is words and sentences which have a deeper implication than merely figure or frequency. Qualitative research provides complex details about phenomenon that is difficult to interpret using quantitative (statistics). This research seeks information from the research object by describing all symbolic systems that can provide in-depth understanding (Sutopo, 2002: 35).

The main source of data is the manuscript of History of The Land of Java transliterated and translated by Sudibjo Z. H. written in the form of prose (in Javanese: gancar). The data used in the research is intrinsic elements that build the text as a whole.

This research is an attempt to make use of a solid document. The most commonly applied technique is content analysis. This technique is used to support the interpretation of a text being analyzed. Yin states that in content analysis, the researcher does not only take notes of important substances directly stated in the document or archive, but also the implied meaning (Sutopo, 2002: 70-71). Therefore, a content analysis is needed to seek information more deeply in order to obtain the best result.

Since the research data is intrinsic elements in literatures, deconstruction theory, a further structural analysis technique, is needed to collect the data. Deconstruction means reducing the construction intensity (Kutha Ratna, 2007: 245). Structuralism deconstruction requires repeated readings by reducing the proportion of binary opposition so that dominant element does not always dominate the other element. In brief, all the elements that exist in the text either explicitly or implicitly are given the attention proportionately.

Deconstructive reading opens up for other possibilities to reinterpret the epistemology built by a text. This means that the thinking concepts in cultural aspect (symbolical) can always be deconstructed, because they are manifested in textual language (Audifax, 2007: 49). The foundation of deconstructive analysis is the view that social, linguistic, and philosophical sciences will be delimited by thinking category contradiction and language categories almost in all scripts (Derrida, 2002: 41).

Deconstructive analysis is used in this research to observe the political strength of Java and Dutch colonialists in the same and equal proportion as the conventional meaning presentation delay and the differentiation of political motives at the same time to offer a possibility for different interpretations of a text.

\section{Result and Discussion}

\subsection{Deconstructive Analysis}

Sultan Agung Hanyakrakusuma responded to the initial information about the presence of Dutch people in Jayakarta (BTJ-S: 176) by commanding his soldiers to invade the colonization of the Dutch in Java using military power. As explained by the text, the soldiers sent by Sultan Agung did not lose; instead, they received a command to return to Mataram. BTJ-S text recounts that the colonialists started to intervene with the political 
life of Java since the reign of Sultan Agung's grandson, Susuhunan Amangkurat II who then ruled in Kartasura Palace. Amangkurat II was even well known as the son of the colonialists. The issue rose because Amangkurat held the title "Amangkurat Amral" and liked to dress like a Dutch. The word "Amral" refers to the word "admiral."

Since the reign of Amangkurat II, Dutch colonialists started to play a significant role in every governmental policy of Javanese Kingdom (Mataram). By reading the text on the surface, it may be concluded that the Dutch colonialists have a big role in the presence of the King, regents, and dukes of Java. In the analysis of BTJ-2 script, a hypogram is led by episodes in the text. The BTJ-S text creates a big theme built on several motives. The motives discussed in this research are:

\subsubsection{Prophecy Motive}

The prophecy motive in BTJ-S is presented as omen. Omen in Javanese belief refers to a singular truth, the nature, how something or someone is destined to be (in Javanese: jangka); and differs from forecast or prediction. What influenced Sultan Agung Hanyakrakusuma to withdraw his soldiers? It was told that there was only one troop of Dutch military force left in Jayakarta when Mataram soldiers invaded. If this had been true, it would have been very easy for Mataram troops to defeat Dutch military force whose religious belief conflicted with Islam, the religion believed by most Javanese people. The defeat of Dutch military force by the Javanese was caused by two reasons. First, the Dutch was considered a threat for Mataram territory. Second, due to their religious belief, the presence of Dutch people in Java was not accepted, considering the Sultan himself was a religious (Islamic) leader in addition to the leader of the nation.

The withdrawal of Mataram soldiers as described by the author of History of the Land of Java creates a perception that Sultan Agung was a wise figure and had prophesying ability (in Javanese: waskitha). After the incident, the Dutch gathered its people to go to Mataram to present gifts for the Sultan because they were given mercy (BTJ-S: 180). Every king of Java mentioned in BTJ-S had prophesying ability to foresee what will happen in the future. After the battle against Jayakarta, Sultan Agung said to Pangeran Purbaya,

"Uwa, memang betul paduka (bahwa kedatangan Belanda ke Jayakarta hanya untuk berdagang). Memang sudah menjadi kehendak Tuhan bahwa orang-orang Belanda itu kelak akan membantu pada anak turun saya, yang bertahta lestari sebagai raja. Jika kelak keturunan saya ada yang kalah dalam peperangan, mereka akan ditolong oleh orang-orang Belanda"

"Uncle, it was true (that the arrival of Dutch people in Jayakarta is merely for the reason of trade). It has been destined by God that the Dutch people will help our descendants in the future who rule as king. If in the future one of my descendants loses in a battle, they will be helped by the Dutch people", (BTJ-S: 179-180).

The author of BTJ-S indirectly states that the presence of Dutch people in Java is much needed by the next kings of Mataram to maintain their sovereignty. Therefore, Sultan Agung intentionally let them stay in Jayakarta (Jakarta). This means that the presence of Dutch people at that time was not considered a threat for Mataram. People saw the king as God's direct messenger since the king has the ability to foresee the future, in addition to hermits who had natural insight.

The successor of Sultan Agung was his son who held the title Kanjeng Susuhunan Mangkurat Senapati Inggalaga Ngabdurrahman Sayidinpanatagama" (Amangkurat I). In the beginning of his reign, things were going quite smoothly. However, when he became older, his son and a rebel named Trunajaya plotted to overthrow the king. Trunajaya rebellion succeeded to invade Mataram; but in the end, Trunajaya wanted to rule Mataram by himself. Before his death during his escape to Banyumas, Amangkurat I said his prophecy to his son as follows:

“...karena saya sudah tidak diizinkan oleh Allah untuk menjadi raja lagi...” (BTJ-S: 223), "kelak setelah saya tiada, pergilah engkau meminta bantuan orang Belanda...orang Belanda akan menang perangnya, semua anak cucuku kelak, jika berteman dengan orang Belanda tentu akan menang perangnya...jangan lupa membawa teman orang Belanda” (BJT-S: 224).

“...since God no longer allows me to be a king..." (BTJ-S: 223), "later when I die, go ask for help from the Dutch...the Dutch will win the battle, all my descendants in the future, if you ever become friend with the Dutch, you will win your battle...don't forget to bring a Dutch friend.” (BJT-S: 224).

For Javanese people, everything happens is destined by God. This means that Javanese people after the era of Hinduism still believed in prophecy, which is a centered will from God (Allah) with some people chosen to receive the sign. In other words, the presence of VOC (Vereenigde Oostindische Compagnie, Dutch East India 
Company) was a great cosmic plan in the establishment of the United Nation of the Republic of Indonesia (Negara Kesatuan Republik Indonesia/NKRI). This issue is related to Javanese cosmology belief. Prophecy motive is often mentioned in each episode of the BTJ-S script, from the first episode to the last ones. During the reign of Amangkurat II and his descendants, Dutch colonialists had an important role in every policy made by the Kingdom. Genealogy with prophecy motive needs to be understood from literary approach instead of historical approach, since historical literatures (babad) show the uniqueness of culture in three aspects: the product of human's work, social behavior, and the society's way of thinking (Koentjaraningrat, 1984:5-6).

\subsubsection{Mutualism Political Motive}

The discussion on prophecy motive provides a description about the role of Dutch colonialism in preserving the hegemony of Mataram Dynasty after the reign of Sultan Agung. The arrival of Dutch colonialists in Java was initially intended for trade interest only. The BTJ-S text states that the Dutch often destroys the countries they visit through wars. Only in Java, they allied with the government (the Kingdom). Their intention was to get a business (trading) license from Mataram. The Dutch always asked for reward for their services to the king of Mataram. The reward they wanted was any land conquered by Mataram, without having to pay for land tax to the Kingdom (BTJ-S: 439). The character of Dutch people was also narrated by Ki Suraadimenggala:

\section{“...Tabiat orang Kompeni itu sangat kurang ajar; jika sudah mendapat tempat berpijak tentu naik ke} bahu. Artinya, jika dituruti satu permintaannya, terus akan bertambah lagi keinginan yang lain" (BTJ-S: 366).

"The character of the Dutch people was very insolent; when they get a place to step on, they will climb on to your shoulders. In other words, if you grant one wish of theirs, they will ask for more." (BTJ-S: 366).

The Dutch colonialists were depicted as being clever in making use of any conflicts between Javanese leaders. As an example, they made a request to Sinuhun Pakubuwana I to assassinate Dipati Jangrana from Surabaya; and if their request was not granted, their leader would break their partnership with Sinuhun and then allied with Sunan Mangkurat Mas (Mangkurat III) who, at that time, was a fugitive of Sinuhun Pakubuwana I (BTJ-S:389-391).

During the reign of Mangkurat II, Mataram was about to break their partnership with the colonialists by getting rid of Dutch soldiers in Jepara (BTJ-S: 290). However, as suggested by Prince Puger (who then became Pakubuwana I), Mataram faced the Dutch with an open manner. The closed conflict between Mataram and the Dutch colonialists began with the battle of Untung Surapati.

The mutualistic politics established between Mataram and the Dutch colonialists were: (1) Mataram needed Dutch military power to strengthen their military base to deal with revolutions occurred in some areas in Java, (2) Mataram needed formal legal recognition from the Dutch council in Batavia to preserve the existence and hegemony of Mataram, (3) The colonialists needed trading license in Java from Mataram, and (4) The colonialists wanted to gain as much profit as possible by monopolizing trade in the coastal areas of Java as a reward for helping Mataram's military power.

In brief, the colonialists only wanted to collaborate with the strongest leader of Java (the King of Mataram). They did not want to get involved with any conflicts of fighting for power. Their principle was; whoever the king of Mataram was, the Dutch would serve and collaborate with the king.

The colonialists always sent their soldiers to maintain the security of the king of Mataram in Kartasura Palace. This should not only be seen as the Dutch's way to observe Mangkurat and Pakubuwana's government; this was also their way to serve the king of Java. This convention is based on literature comprehension, not historical approach. From this escorting issue, it can be seen that there was a political strategy of keeping an eye on each other for the sake of both parties. The two parties, Mataram and the Dutch, did not want to lose control over each other.

\subsection{The Political Life of Mataram Dynasty}

The philosophy of "satya wacana" or keeping promises (in Javanese: Sabda Brahmana Raja datan kena wola-wali) was practiced by the colonialists to use the power of the kings of Java. By using preexisting treaties, the colonialists without restrictions were able to control the situation in Java. In addition, they always attempted to renew the preexisting treaties. Since the colonialists always asked for land from the King of Mataram, Mataram's economy region of food and trade became smaller. The power of the colonialists started to overtake the power of the King of Mataram after Mangkurat I. This was proven by the surrender of Mangkurat Mas and a duke in Madura to the colonialists. The Dutch colonialists were considered providing asylum from the threat of 
Mataram. However, many episodes in the text mention that whoever surrendered to the colonialists, their surrenders were always reported to Sinuhun Mataram. This suggests that the colonialists were afraid of the power of the King. In other words, the colonialists did not dare to break their partnership with the King of Mataram.

In one episode, when Prince Puger (Pakubuwana I) rebelled from his nephew (Sinuhun Mangkurat III), he received support from the colonialists. BTJ-S mentions that the colonialists disliked the characters of Pakubuwana II because unlike his predecessors, he was considered an arrogant king.

With the power and loyalty of the regents and dukes from Surabaya, Madura, and all coastal areas in Java, Prince Puger did not need any help from the colonialists to become a king in Kartasura. The coronation is described in BTJ-S as an easy process. As long as a person is of Mataram descendant, he had the rights to independently claim himself as a king-legally and formally after he succeeded to invade and occupy an ancestor's palace. This situation disturbed the tranquility of the society, because Javanese people became confused of who their actual leader was.

The role of Dutch colonialism in Javanese political life began when Dutch military soldiers helped Mangkurat II to overthrow Trunajaya as the king of Mataram. Since then, Mangkurat II felt that he had a moral duty towards the colonialists. This moral duty politics was then used by the colonialists to threat Mangkurat II. They started to confidently request for the deaths of the King's men (in Javanese: sentana) who were considered harmful for their presence in the land of Java. The second role of the colonialists was helping Prince Puger to takeover Mataram from the throne of Mangkurat III. Third, the colonialists helped Pakubuwana I start a revolution in Surabaya and Madura. Fourth, they helped Pakubuwana II deal with revolutions done by his younger siblings. In the beginning, the colonialists used military politics. Afterward, they started to provoke the economic politics by asking for Mataram's colonies that were potential for gaining profits in trade.

The colonialists' policy in Java was established due to several motives: (1) Establishing dependence of Mataram to the colonialists, (2) Using careful consideration in every action, and (3) Pleasing the noblemen (officials) in Java.

BTJ-S does not indicate the use of devide et impera politics, which is a political strategy done by dominating a group of people to colonize and disunite them. Devide et impera politics was used by the colonialists after Mataram was disunited into two palaces in Surakarta and Yogyakarta during the early $18^{\text {th }}$ century (ARA collection of Van den Bosch No. 220 f. 303 in Hauben, 2002:148).

BTJ-S explains that the colonialists could never provide resolution for the conflicts happened in Java and the crisis in Mataram Dynasty (the succession of wars in Java). The initiative to resolve the Kingdom's problems was in the hands of Javanese political figures. Conventionally, the King of Mataram was merely a symbol, while all of the nation's affairs were under the responsibility of a Mahapatih (Prime Minister). Every policy established by the Kingdom was based on conventions of the royal family members and important officials in Mataram government.

The lack of authority of the Dutch colonialists in intervening internal problems of the Kingdom is stated in the last episodes of BTJ-S, when Prime Minister Danureja reprimanded a Dutch commissary called Dulkup because he appointed a regent in Semarang without the authorization from the King in Kartasura. Feeling guilty, the commissary asked for the Prime Minister's mercy to not to report the incident to the King. The Prime Minister sent a letter to affirm the position and authority of the colonialists in Semarang. The letter stated that the colonialists were not given the authority to appoint a regent in an area-they only had the rights to supervise the job; and if the regent made a mistake, they were allowed to give punishment.

BTJ-S does not view the presence of Dutch colonialists in Java as a threat for the future. As a foreign nation, the Dutch was only considered a political and military partner that can be relied on in several aspects. The main point the BTJ-S text considers dangerous is the disunity among Javanese leaders that needed to be resolved and reunited for the sake of sustaining single leader hegemony in Java.

\subsection{The Function of BTJ-S}

A historical literature (babad) has a function outside of the text. The first function is giving legitimization to leaders. By giving legitimization, a babad also holds the function as mystical literature (Berg, 1985:41). BTJ-S provides information about the ancestry of Mataram Dynasty who had the legal rights of Mataram throne and to rule the entire Java. The ancestry was written as predecessor genealogy of Mataram. BTJ-S provides a clever description of how Javanese politicians viewed the presence of Dutch colonialists in Java. BTJ-S provides centralized legitimization, which is the legality of Mataram government that ruled the entire Java. 
The motives found in the research illustrate how large the Kingdom of Mataram was, and how it could rule almost the entire Java. BTJ-S always recounts the complexity of human's life, the sustainability of the dynasty, and the dynasty's struggle to deal with themselves and the society. BTJ-S also functions to inspire people to always be careful in politics; to always be cautious in facing strangers, even when the strangers are from the same nation or family. BTJ-S provides an overview of the governmental system during Mataram era; political policies, military policies, and culture.

\section{Conclusion}

The conclusion of the research is that the universality of BTJ-S is dense with information on the wars and battles of the leaders of Java. The author of BTJ-S illustrates the horrifying situation during the war of conquest and the succession of wars in Java of fighting over the throne of Mataram dynasty. The non-stop wars resulted in food crises and political, social, and mental instability. From the first to the last episodes, BTJ-S gives the readers stories about conquest, assassination, and revolution. BTJ-S also delivers the philosophy of the spirit of military patriotism and devotion for the knights of Java.

The constant war caused the Dutch colonialists to go through an economic crisis, which made them have to ask for rice from Pakubuwana I to support the life of their soldiers in Kartasura. For the colonialists, the most important thing was peace and stability with as low cost as possible (see Ricklefs, 2002:160). The role of Dutch colonialists in the political life of Mataram Dynasty began in the era of Susuhunan Mangkurat II and this partnership was continued by the next kings of Mataram. The colonialists and Mataram controlled and kept an eye for each other with the intention of mutual benefits.

Since literatures are closely related to cultural situations, it is encouraged to conduct researches using literary works as objects on different perspectives. A historical literature (babad) contains a society's ideas, concepts, and way of thinking in a certain era. These ideas, concepts, and way of thinking build the culture of the past. By learning the culture of the past, we can build the culture of the present.

\section{References}

Audifax. (2007). Semiotika Tuhan: Tafsir atas Pembacaan Manusia Terhadap Tuhan. Yogyakarta: Pinus Book Publisher.

Berg, C. C. (1964). The Role of Structural Organization and Myth in Javanese Historiography: Commentary. The Journal of Asian Studies, 24(1), 100-103. http://dx.doi.org/10.2307/2050417

Berg, C. C. (1985). Penulisan Sejarah Jawa. Jakarta: Bhatara Karya.

Day, A. (1978). Babad Kandha, Babad Kraton and Variation in Modern Javanese Literature. Bijdragen tot de Taal-, Land-en Volkenkunde, 134(4), 433-450. http://dx.doi.org/10.1163/22134379-90002580

Derrida, Jacques. (2002). Dekonstruksi Spiritual (saduran Firmansyah Argus). Yogyakarta: Jalasutra.

Fitzpatrick, E. B. (2008). The Public Library as Instrument of Colonialism: The Case of the Netherlands East Indies. Libraries \& the Cultural Record, 43(3), 270-285. http://dx.doi.org/10.1353/lac.0.0034

Hartarta, A. (2011). Mencerap Karya Sastra in Peranan Bahasa, Sastra, dan Budaya Jawa dalam Membentuk Karakter Bangsa. Solo: FSSR Publishing.

Houben, Vincent J. H. (2002). Keraton dan Kompeni: Surakarta dan Yogyakarta, 1830-1870 (translated by E. Setiyawati Alkhatab). Yogyakarta: Bentang Budaya.

Johns, A. H. (1964). The Role of Structural Organization and Myth in Javanese Historiography. The Journal of Asian Studies, 24(1), 91-99. http://dx.doi.org /10.2307/2050416

Koentjaraningrat. (1984). Kebudayaan, Mentalitas, dan Pembangunan. Jakarta: PT Gramedia.

Kumar, A. L. (1984). On Variation in Babads. Bijdragen tot de Taal-, Land-en Volkenkunde, 140(2), 223-247.

Kutha Ratna, Nyoman. (2007). Sastra dan Cultural Studies: Representasi Fiksi dan Fakta. Yogyakarta: Pustaka Pelajar.

Ras, J. J. (1986). The Babad Tanah Jawi and its reliability: Questions of content, structure and function. In C. D. Grijns, \& S. O. Robson (Eds.), Cultural Contact and Textual Interpretation. Dordrecht, the Netherlands: Foris Publications.

Ras, J. J. (1987). The Genesis of the Babad Tanah Jawi: Origin and Function of the Javanese Court Chronicle. Bijdragen tot de Taal-, Land-en Volkenkunde, 143(2), 343-356. http://dx.doi.org/10.1163/2213437990003331 
Ricklefs, M. C. (1979). The evolution of babad tanah jawi texts: in response to day. Bijdragen tot de Taal-, Land-en Volkenkunde, 135(4), 443-454. http://dx.doi.org/10.1163/22134379-90003544

Ricklefs, M. C. (2002). Yogyakarta di Bawah Sultan Mangkubumi 1749-1792: Sejarah Pembagian Jawa (terjemahan Hartono Hadi Kusumo dan E. Setiyawati Alkhatab). Yogyakarta: Matabangsa.

Sutopo, H. B. (2002). Metodologi Penelitian Kualitatif. Surakarta: Sebelas Maret University Press.

Sudibjo Z. H. (1980). Babad Tanah Jawi. Jakarta: Proyek Penerbitan Buku Sastra Indonesia dan Daerah, Dep artemen Pendidikan dan Kebudayaan.

Teeuw, A. (1984). Indonesia as a 'Field of Literary Study' A Case Door W. L. Olthof. Dordrecht: Foris Publication.

Teeuw, A. (1988). Sastra dan Ilmu Sastra: Pengantar Teori Sastra. Jakarta: Pustaka Jaya.

Wieringa, E. P. (1999). An Old Text Brought to Life Again: A Reconsideration of the 'Final Version' of the Babad Tanah Jawi. Bijdragen tot de Taal-, Land-en Volkenkunde, 155(2), 244-263. http://dx.doi.org/10.1163/22134379-90003876

\section{Copyrights}

Copyright for this article is retained by the author(s), with first publication rights granted to the journal.

This is an open-access article distributed under the terms and conditions of the Creative Commons Attribution license (http://creativecommons.org/licenses/by/3.0/). 